\title{
Research on improving graduation design of engineering majors
}

\author{
Liu Suolan, Kong Lizhi ${ }^{*}$, Huan Juan \\ Changzhou University, Changzhou 213164, China \\ E-mail: liusl@cczu.edu.cn
}

Keywords: graduation design; reform measures; quality

Abstract: In this paper, we investigate main problems in engineering graduation design, study and analyze reasons of these problems from several aspects. Then several measures are provided to solve them, including educational system, teacher management, student management, and process management of graduation design. The aim of this research is to use the period of time efficiently to ensure practical teaching and graduation design quality.

\section{Introduction}

Graduation design is an important process of deepening and sublimating of study. It's also a close link between learning and practice, research and practice. Furthermore, it is an improving cultivated stage of innovative thinking, comprehensive quality and engineering practice. At the same time, graduation design is not only an important basis for the students' graduation and degree certificates, but also a key index of evaluating education quality and efficiency. Graduation design can test students' comprehensive ability of using the professional knowledge, and the ability to analyze and solve practical problems. It is an important link in cultivation students' innovative thinking and creative abilities. At present, most colleges and universities have put high emphasis on graduation design, but there are still many problems. According to the investigation of engineering specialized training plan in domestic universities, graduation design work is usually arranged in the eighth semesters. However, the actual duration often ranges from 3 to 5 months. Therefore, how to use the period of time efficiently to ensure practical teaching and graduation design quality is a realistic problem faced in engineering colleges. In this paper, we study and discuss the problems related to engineering graduation design, and put forward some measures of teaching reform.

\section{Analysis of engineering graduation design status}

Although graduation design can improve students' ability of using professional knowledge and comprehensive quality, but there are still many problems in the process, some prominent are shown as follows:

(1) Contradiction between enrollment and employment. Since 1999, higher education in china is in the historical process, that is, from scale expansion to connotation development and education resources and education layout are adjusting. And China has entered the popular stage of higher education. However, undergraduate education also uses the old mode "tough to get in but easy to get out”. In this mode, the general hope is students can graduate, so the teaching management department in Colleges and universities is intrinsically difficult to support teachers who are strict with students, accordance with the requirements of graduation design. So why can the old mode still exist? The reason is that the old model has persisted many years and been a habit, though it is not adapted to the current undergraduate education. The second reason is that many higher colleges pursuit employment rate, because the employment rate affects reputation and enrollment. "easy to get out seems can help to improve the employment rate on the face. Actually, in the long run, the old mode of "easy to get out” will eventually lead to employer's dissatisfaction, and do nothing to 
improve the employment rate.

(2) teachers' problems. Work of guiding students' graduation design is not enough. The current teacher evaluation system let many young teachers put time and energy for improving their scientific research level. They have to take part in the research involved in longitudinal project, and research results are mainly embodied in the writing of "high quality" academic papers. This causes the teacher put a small amount of time to graduation design, the students are lack of effective guidance and training, which directly affects the quality of graduation design. On the other hand, many teachers are lack of practical experience, especially young teachers who are engaged in teaching directly after graduation. Therefore, their guidance capability is not enough. They cannot put their own research and graduation design work together. Furthermore, the content of the teacher's scientific research project is meaningful for a small group who are ready to be master degree candidates. But for the other who are ready to take part in job, the research content is general partial theory, and does not match with the social actual demand and festival. It is not right to be graduation design topics.

(3) student's level and attitude. With the development of Internet, temptation of network such as online games, audio and video is also increasing. Willpower weak students may be addicted to the Internet. Therefore, the network will spend them a lot of time, In addition, the network will develop students' inert. To computer professional students there are several times in class experiments and multiple practice curriculum, but many students can easily get the answer through the network, practice opportunities are wasted. As a result, their practical ability is poor. And they are lack of self-confidence while solving problems. It is also one of the reasons of graduation design quality declining. At the same time, the employment pressure has great influence on the students. Some students are pursing of obtaining kinds of certificates. Some of them do not help to improve their ability to analyze and solve problems. They have to put too much energy into a variety of recruitment examination and related occupation. They are so busy as not taking into account the graduation design topic selection, document collection, designing and thesis writing, which led to the decline in the quality of graduation design.

\section{Several measures for improving the situation and graduation design quality}

According to the analysis of the existing problems, we can conclude that reasons of influence graduation design quality and restricting students ability are not only teaching, but also involves many factors, especially the undergraduate teaching management and cultivating system. So, on the basis of graduation design's important status, we must reform the existing teaching management mode, integrate graduate design link scientifically, strengthen the professional ability, guide and cultivate the students' ability of practice and innovation step by step. Only in this way, can we improve its quality and let graduation design play its effect.

(1) Reform education system from top to bottom, change the mode of "easy to get out" to " tough to get out" gradually. At the same time, to ensure the rationality of "tough to get out”, we should reduce the proportion of higher education cost sharing, or for students from poor families to provide unsecured loan. Meanwhile, the school should make related rules and effectively support implementation. In this way, guidance and management of teachers can be effective, and students can change the pressure into motive force, to complete the graduation design, which makes the graduation design does become a practical exercise before working.

(2) Strengthen construction of teachers team as well as software and hardware, improve teacher-student ratio. And offer learning, training, and studying opportunities for teachers to update knowledge. Improve teachers' sense of responsibility and enthusiasm. Develop guidelines 
considering theory research and technology research in the process of teachers evaluation assessment, in order to facilitate the teachers to conduct theoretical research or technology development according to their own interest and director, instead of application and research against their interest all the pursuit of longitudinal project of National Natural Science Funds etc. Encourage teachers to carry out various types of scientific research, which can create more opportunities for undergraduates to know technology trends and social needs and obtain more practice and opportunity to think. All these have great advantage to improve graduation design level.

(3) As students, we should be aware of the importance of study, in addition to theory courses, for each experiment and experiment course, should complete it by ourselves, on the basis of discussion with students and guidance of teachers. Thus, our ability of practice and innovation ability can be gradually improved. Students should learn to select relevant information of certificates, so as not to delay the learning in the classroom. Students should also learn to relieve the pressure of employment, reasonable arrangements to do graduation design and hunt job, as soon as possible to complete the graduation design better, and regard graduation design as their practice experience for the job interview. In addition, colleges and university also should pay attention to employment guidance, and try to provide students with the employer, provide employment recommendation, and become a solid bridge between students and society.

(4) Pay close attention to the process management of graduation design. In order to improve the quality of graduation design, universities and second grade colleges should have the corresponding system to regulate and restrain the teachers guidance to finish the important teaching process. In the process of making system, restriction and encouragement should be fully considered, Nothing can be accomplished without norms or standards. If the constraint is not specifical, it does not have operationability. Some teachers and students will do things carelessly. Reward will encourage teachers and students to actively complete the graduation design. Clear the responsibility of the teacher, such as guiding the students to do topic selection, providing the necessary documentation, modifying design ideas, preparing opening report, writing final paper, and giving performance evaluation. Of course, we should also require students to complete their work. At the same time, the system should be changed with the times. In the past cyber source was not particularly rich, plagiarism phenomenon was scarce. But now, it becomes more and more prominent. Therefore, when students submit papers, check reports are needed. If repeated proportion exceeds a threshold, the student will lose the opportunity of thesis defense. If it is especially serious, graduation degree will be canceled. In order to improve the quality of graduation design, corresponding reward is also essential, if student's graduation design is outstanding, material reward and honor certificate should be offered to both the student and teacher. And give priority to the teacher. This can improve the enthusiasm of teachers and students so as to upgrade the quality of graduation design.

\section{Summary}

In this paper, we integrate the experience of teaching and guidance of graduation design. Investigate main problems under the current situation of undergraduate engineering graduation design. Study and analyze reasons of these problems from four aspects including educational system, teacher management, student management, and process management of graduation design. And then discusses the methods of solving them. We think that the institutional change is the key to improve the quality of graduation design. It affects teachers and students attitude. Teachers should pay attention to the latest technology, know the needs of society, and actively participate in various 
scientific research projects to improve professional level. In addition, guide the students to be good at, as well as be willing to do the graduation design, and benefit from it. This can also improve graduation design quality effectively.

\section{Acknowledgements}

This work is supported by the following projects: Research Project of Changzhou University(GJY12020056, GJY20130071); National Natural Science Foundation of China (Grant No: 21204005).

\section{References}

[1] Hyder, Imran; Arnold, Drew; Calvo-Amodio, Javier; Parmigiani, John P. Using graduate assistants as project advisers for externally-sponsored capstone design projects[J].International Journal of Engineering Education, 2014,30(1):101-111

[2] Igor M. Verner; Eyal Hershko. School graduation project in robot design: a case study of team learning experiences and outcomes[J]. Journal of technology education, 2013,14(2):40-55

[3] Wang G L. Research and practice on graduation design of civil engineering in applicationoriented undergraduate institutes[J]. Advanced Materials Research, 2014: 3190-3194.

[4] Doloswala, Kalika Navin; Thompson, Darrall; Toner, Phillip. Digital based media design: The innovative contribution of design graduates from vocational and higher education sectors[J]. International Journal of Technology and Design Education, 2013,23( 2) :409-423.

[5] Cooke, Harry G; Dunn, Todd; Wolcott, Scott B. Preparedness of civil engineering technology graduates for design careers[J].120th ASEE Annual Conference and Exposition, 2013. 